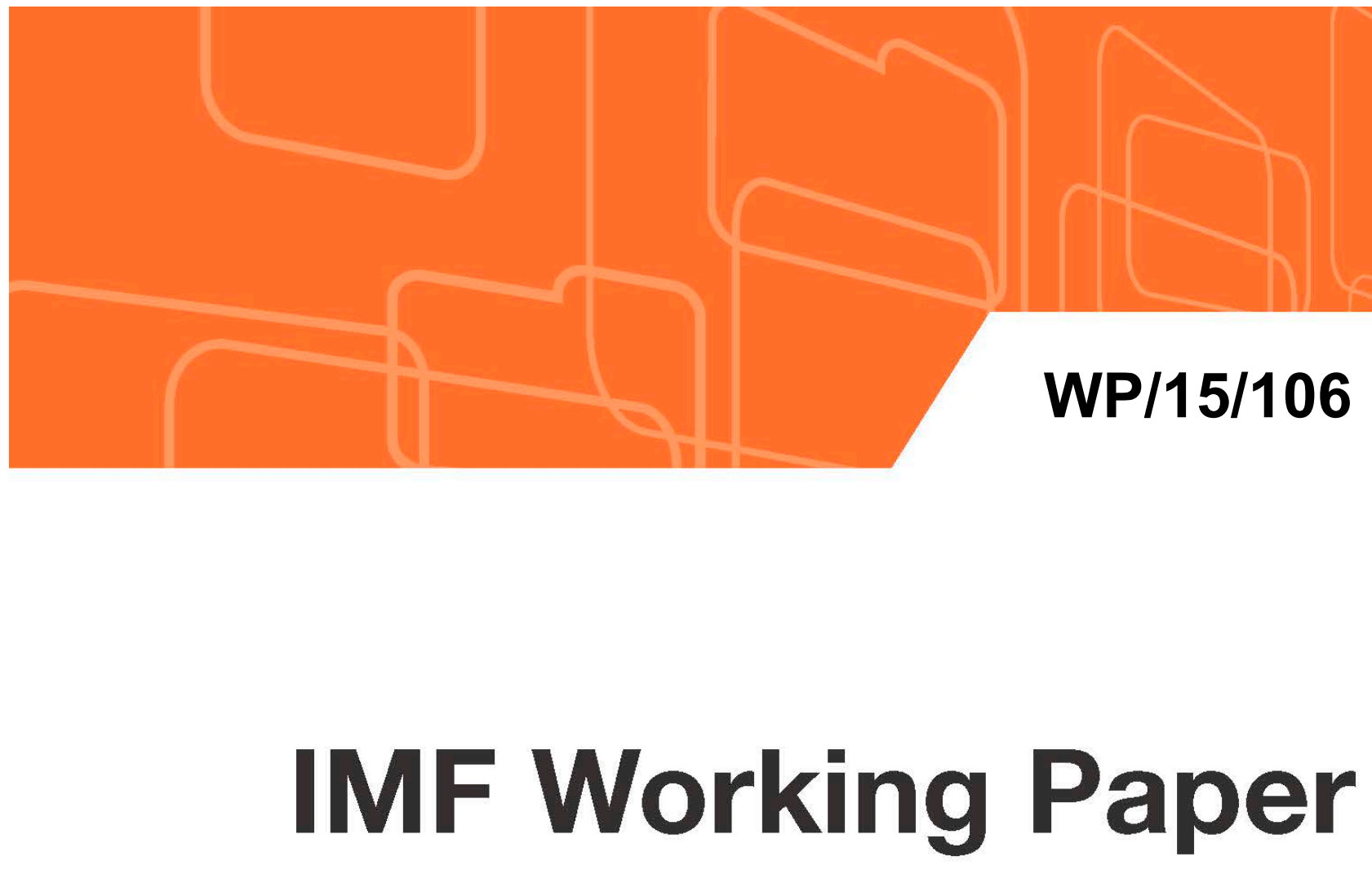

\title{
Issuance of Central Bank Securities: International Experiences and Guidelines
}

by Simon Gray and Runchana Pongsaparn 


\title{
IMF Working Paper
}

Monetary and Capital Markets Department

\section{Issuance of Central Bank Securities: International Experiences and Guidelines Prepared by Simon Gray and Runchana Pongsaparn ${ }^{1}$}

Authorized for distribution by Ghiath Shabsigh

May 2015

\section{IMF Working Papers describe research in progress by the author(s) and are published to} elicit comments and to encourage debate. The views expressed in IMF Working Papers are those of the author(s) and do not necessarily represent the views of the IMF, its Executive Board, or IMF management.

\begin{abstract}
The paper discusses the reasons for central bank (CB) issuance of securities, and reasons for choosing different approaches e.g. in maturities and target market. It provides evidence on the range of different approaches taken by those CBs which do issue, as well as suggesting reasons why some $\mathrm{CBs}$ do not; and provides operational guidelines on the major building blocks of the issuance of CB securities.
\end{abstract}

JEL Classification Numbers: E58; G10

Keywords: central bank securities, liquidity management, securities market development Author’s E-Mail Address: sgray@imf.org; rpongsaparn@imf.org

\footnotetext{
${ }^{1}$ The authors would like to thank Miguel Savastano, Ghiath Shabsigh, Bernard Laurens, Kelly Eckhold, Mariam El Hamiani Khatat, Manmohan Singh, and Zsolt Ersek for detailed comments and suggestions.
} 
Contents Page

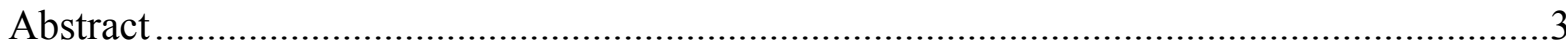

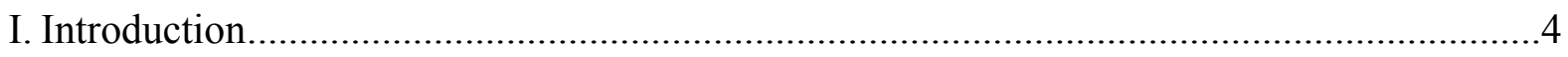

II. Stylized Facts on Central Bank Securities Issuance: A Global Context ...............................6

A. What are the Characteristics of Central Banks Issuing Securities? ...........................6

B. Why Do Central Banks Issue Securities?................................................................

III. How Do Central Banks Issue Securities? ....................................................................12

A. Treasury or Central Bank Bills for Liquidity Management? ....................................13

B. Central Bank Securities Issuance: Operational Issues ..............................................14

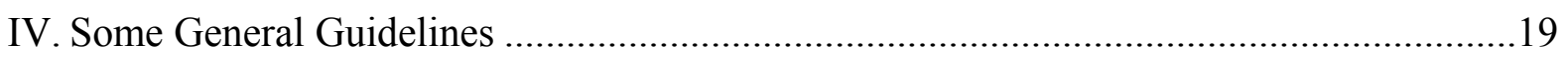

A. The Allocation of Open Market Operation Instruments .........................................19

B. Planning the Issuance of Central Bank Securities...................................................20

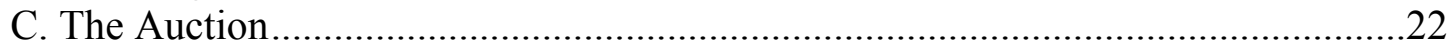

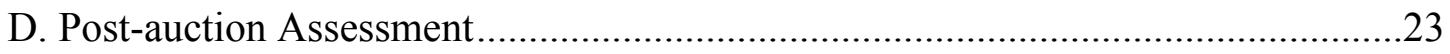

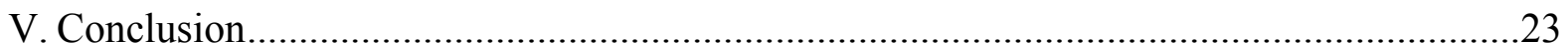

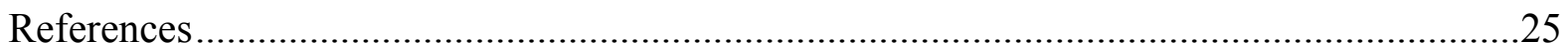

Tables

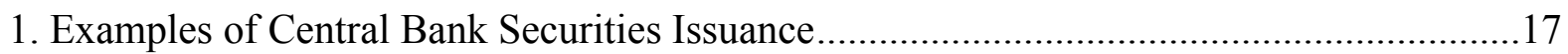

2. Examples of Maturity Ranges by Liquidity Management Instruments ...............................19

Figures

1. Number of Central Banks Issuing Securities-Across Time ……......................................6

2. Number of Central Banks Issuing Securities-Across Regions........................................... 7

3. Number of Central Banks Issuing Securities - by Level of Income...................................... 8

4. Number of Central Banks Issuing Securities - by Monetary Policy Regime .......................... 8

5. Central Bank Legislation and Central Bank Securities Issuance ............................................

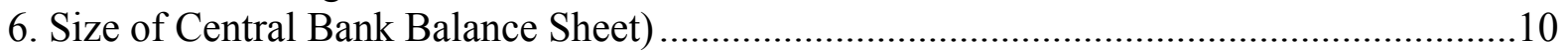

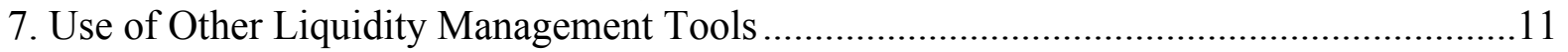

8. Yield Spread and Central Bank Securities Issuance ........................................................11

9. Histogram of Remaining Maturity of CB Securities .......................................................... 14

10. The Process of Central Bank Securities Issuance ..............................................................21

Annexes

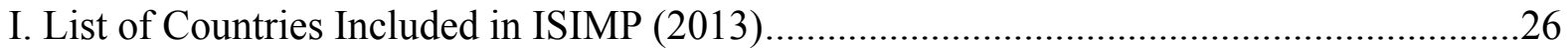

II. Central Bank Securities Issuance - Case Studies of Chile, Korea, and Thailand ................27

III. Bank of Thailand's Planned Issuance for 2014 ................................................................30 


\section{Glossary}

$\begin{array}{ll}\text { BCP } & \text { Chile: Central Bank Peso-denominated Bonds } \\ \text { BCR } & \text { Bid-to-Coverage Ratio } \\ \text { BCU } & \text { Chile: Central Bank Inflation-linked Bonds } \\ \text { BIBOR } & \text { Bangkok Interbank Offered Rate } \\ \text { BOE } & \text { Bank of England } \\ \text { BOK } & \text { Bank of Korea } \\ \text { BOT } & \text { Bank of Thailand } \\ \text { BNM } & \text { Bank Negara Malaysia } \\ \text { BRP } & \text { Bilateral Repurchase Operation } \\ \text { BTP } & \text { Chile: Government Peso-denominated Bonds } \\ \text { BTU } & \text { Chile: Government Inflation-linked Bonds } \\ \text { CB } & \text { Central Bank } \\ \text { CBC } & \text { Central Bank of Chile } \\ \text { CLBD } & \text { IMF: Central Bank Legislation Database } \\ \text { ECB } & \text { European Central Bank } \\ \text { FX } & \text { Foreign Exchange } \\ \text { GDP } & \text { Gross Domestic Product } \\ \text { GFC } & \text { Global Financial Crisis } \\ \text { HKMA } & \text { Hong Kong Monetary Authority } \\ \text { IMF } & \text { International Monetary Fund } \\ \text { ISIMP } & \text { Information System for Instruments of Monetary Policy } \\ \text { IT } & \text { Inflation Targeting } \\ \text { LIC } & \text { Low Income Countries } \\ \text { MCM } & \text { Monetary and Capital Markets Department of the IMF } \\ \text { MPC } & \text { Monetary Policy Committee } \\ \text { MPR } & \text { Monetary Policy Rate } \\ \text { MSA } & \text { Monetary Stabilization Account } \\ \text { MSB } & \text { Monetary Stabilization Bonds } \\ \text { OMO } & \text { Open Market Operation } \\ \text { PDBC } & \text { Chile: Discountable Promissory Notes of CBC } \\ \text { PDMO } & \text { Public Debt Management Office } \\ \text { QE } & \text { Quantitative Easing } \\ \text { RBI } & \text { Reserve Bank of India } \\ \text { RP } & \text { Repurchase Agreements } \\ \text { UF } & \text { Chile: Inflation-adjusted Unit of Account } \\ \text { U.K. } & \text { United Kingdom } \\ \text { U.S. } & \text { United States of America } \\ & \end{array}$




\section{INTRODUCTION}

Most emerging market central banks (CBs) have a long history of operating in a context of surplus reserve balances. $\mathrm{CB}$ balance sheets in these markets have commonly been 'asset driven' whereby the CB takes on certain assets - in particular, foreign exchange (FX) reserves, lending to government, or in some cases lender of last resort (LOLR) assistance to weak banks - whether to serve policy goals or for lack of choice. Doing so generates reserve balances in the accounts of commercial banks which exceed the demand for their use. Since excess reserve balances will tend to depress short-term interest rates (and/or lead to exchange rate pressures), many $\mathrm{CBs}$ undertake sterilization operations to minimize adverse consequences. This may involve increasing reserve requirements, paying interest on excess reserves, using instruments such as term deposits, reverse repo (or FX swaps), or the issuance of CB bills.

In recent years a number of advanced economy banking systems have moved from a structural deficit of reserve balances to a structural surplus as a result of the Global Financial Crisis (GFC). In Japan, the U.S. and the U.K. ${ }^{2}$, CB purchases of securities (Quantitative Easing (QE)) have resulted in substantial balance sheet increases and large excess reserve positions held by commercial banks, while in the euro zone, liquidity provision via lending to banks, in response to the GFC, has also led to excess reserve balances.

In addition, a surge in cross-border capital flows following the GFC has renewed the challenges for emerging market $\mathrm{CBs}$ in the effective management of reserve balances. Initially, many emerging market economies experienced capital outflows as financial institutions pulled liquidity back to the U.S. and Europe. The sale of FX by CBs, to smooth exchange rate depreciation, drained excess domestic-currency reserve balances. But shortly thereafter, loose monetary policy (notably QE) in response to the GFC reignited capital inflows into emerging markets, putting upwards pressure on their domestic currencies. ${ }^{3}$ To ward off such pressure, FX intervention has been common, causing an increase in domestic currency reserve balances. To avoid an adverse consequence on financial stability, careful management of such balances is essential. ${ }^{4}$

\footnotetext{
${ }^{2}$ And prospectively the euro zone, following an European Central Bank (ECB) decision in January 2015.

${ }^{3}$ See for example, IMF (2013) and IMF (2014a).

${ }^{4}$ Commercial banks,' current account balances held at the central bank, or 'reserve balances,' are the part of 'reserve money' (currency in circulation plus commercial bank current account balances at the central bank) which can be directly controlled by the central bank. These balances are often referred to as 'liquidity'; this paper on the whole prefers the term 'reserve balances', since 'liquidity' has wider connotations. For instance, the term 'liquidity' could be used to describe whether a financial instrument is actively traded, or whether there is sufficient third-party funding to support a bank's credit expansion.
} 
Issuance of CB securities may be an attractive option for effective 'liquidity management' as it provides a degree of autonomy to the $\mathrm{CB}$ which is not to be available with all other instruments. Issuance of $\mathrm{CB}$ securities represents one of the most marketfriendly approaches and can be considered as one of the major open market operation (OMO) tools for several CBs. Direct instruments such as reserve requirements normally act as a tax on financial intermediation via commercial banks, unless they are fully remunerated. In a number of countries, recently introduced constraints on commercial bank intermediation have led to the growth of non-bank channels (sometimes referred to as 'shadow banking'), with attendant financial stability risks. The use of other OMO (market friendly) instruments such as the sale of government securities, or using reverse repurchase and FX swaps - relies necessarily on the availability of collateral (or FX) in the CB's portfolio. ${ }^{5} \mathrm{CB}$ securities provide a $\mathrm{CB}$ with autonomy in this respect.

CB securities could also be used to facilitate bond market development purposes. For some countries, a lack of need from the fiscal side may prevent the government from issuing securities in sufficient amount or range of maturities to meet the market demand for domestic currency credit-risk free assets. Issuance of CB securities can fill in the gap and help establish the benchmark yield curve.

This paper seeks to summarize recent cross-country experiences with issuance of CB securities and draw 'best practices' that can serve as an operational guideline for CBs. Existing literature on this particular topic has been rather broad in nature, focusing more on the conceptual side of CB securities issuance. ${ }^{6}$ This paper attempts to bridge the conceptual and practical aspects of $\mathrm{CB}$ securities issuance, covering such issues as differing maturities of issuance, investor access and secondary market trading.

The remainder of the paper is divided in four parts. Section II will provide stylized facts on $\mathrm{CB}$ securities issuance, primarily from a triennial global survey on monetary policy implementation conducted by the IMF's Monetary and Capital Markets Department (MCM) and discuss the rationale for issuing CB securities. Section III will discuss the mechanics of $\mathrm{CB}$ securities issuance, again drawing on international experience. Section IV offers policy guidance and lays out the ingredients and preparations required for CB securities issuance. Section V concludes.

\footnotetext{
${ }^{5}$ In a few cases, a government has been willing to issue securities in excess of its own financing need, placing the surplus cash raised into a blocked account at the central bank. This may reduce the burden on the central bank of sterilizing excess reserves, but there may be constraints on the freedom of the central bank to determine the timing and volume of such issuance.

${ }^{6}$ See for example, Rule (2011).
} 


\section{STYLIZED FACTS ON CENTRAL BANK SECURITIES ISSUANCE: A GLOBAL CONTEXT}

This section provides data to address two questions: (i) what are the characteristics of CBs issuing securities (comparison across time, regions, income groups, and monetary policy regimes)?; and (ii) why do CBs issue securities (liquidity management - either to complement or substitute for other tools — or for bond market development and other purposes)?

\section{A. What are the Characteristics of Central Banks Issuing Securities?}

\section{During the last decade or so, over one third of the world's CBs have been issuing securities to undertake OMO. This is a main finding of the survey on 'Information System for Instruments of Monetary Policy' (ISIMP) conducted by MCM every 2-3 years. In the most recent (2013) survey ${ }^{7} 42 \mathrm{CBs}$ indicated that they issue securities. The share has been relatively stable over the last decade (Figure 1). Comparison across time}

\section{Figure 1. Number of Central Banks Issuing Securities- Across Time}

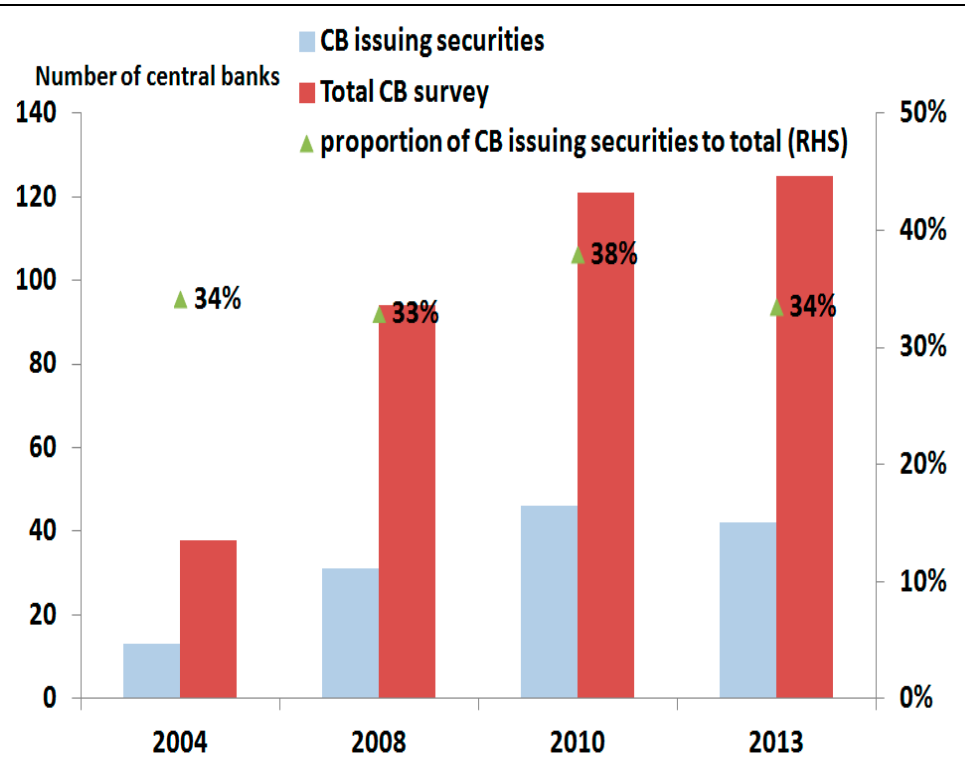

Source: ISIMP and authors' calculations.

should be treated with caution as the country coverage of the survey has expanded substantially over the past few years. Moreover, a closer look into the survey reveals potential inconsistencies, including inconsistent answers over time for the same country as well as data deficiencies. To avoid these inconsistencies, the analysis that follows will focus on the 2013 survey results.

\footnotetext{
${ }^{7}$ The survey covers 125 countries - see the list of countries in Annex I.
} 
As of 2013, the survey shows that CBs in Asia and the Western Hemisphere have been more likely to issue CB securities than CBs from other regions (Figure 2).

These two regions have experienced sizable private capital inflows in the last two decades, and $\mathrm{CB}$ purchases of FX have generated a need to sterilize the excess reserve balances created, as suggested earlier. ${ }^{8}$ In addition to the FX inflows, it may
Figure 2. Number of Central Banks Issuing SecuritiesAcross Regions (2013)

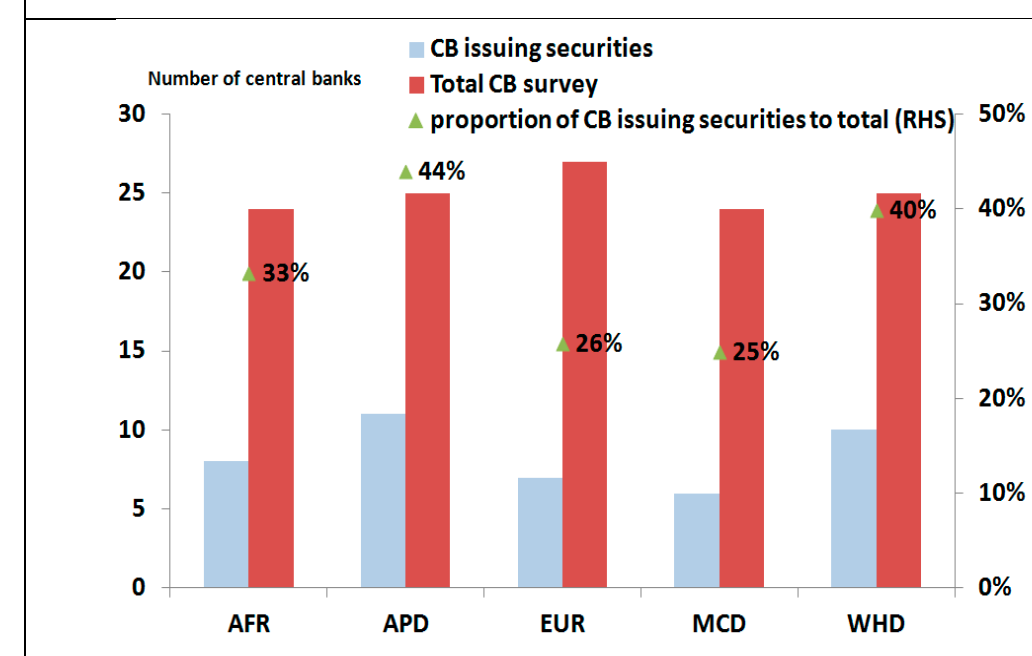

Source: ISIMP and authors' calculations.

Note: AFR (Africa), APD (Asia and Pacific), EUR (Europe), MCD (Middle East and Central Asia), and WHD (Western Hemisphere - the Americas).

be that those countries where the $\mathrm{CB}$ issues securities have, on the whole, a more marketfriendly approach than others.

Issuance of CB securities is much less common among low income countries (LICs). The low-income group has a significantly lower proportion of countries issuing CB securities (Figure 3). Cost concerns, inadequate market infrastructure or market distortions may be hindering the issuance of securities by LIC CBs. It seems unlikely that LIC CBs have a lower incidence of structural surplus liquidity - indeed, they are more likely to have the need to drain surplus reserves than CBs in higher income countries (because of monetary financing and LOLR actions, as well as FX inflows).

\footnotetext{
${ }^{8}$ See also IMF (2013) op. cit.
} 
LIC CBs may choose not to issue their own securities due to the interest rate costs, as well as administrative costs and the lack of a supportive trading, payment, and settlement systems. For some, the cost of draining surplus liquidity at an OMO rate may be seen as too high for their balance sheet. Also, if the market is dominated by commercial banks - so the non-bank

Figure 3. Number of Central Banks Issuing Securities-by Level of Income (2013)

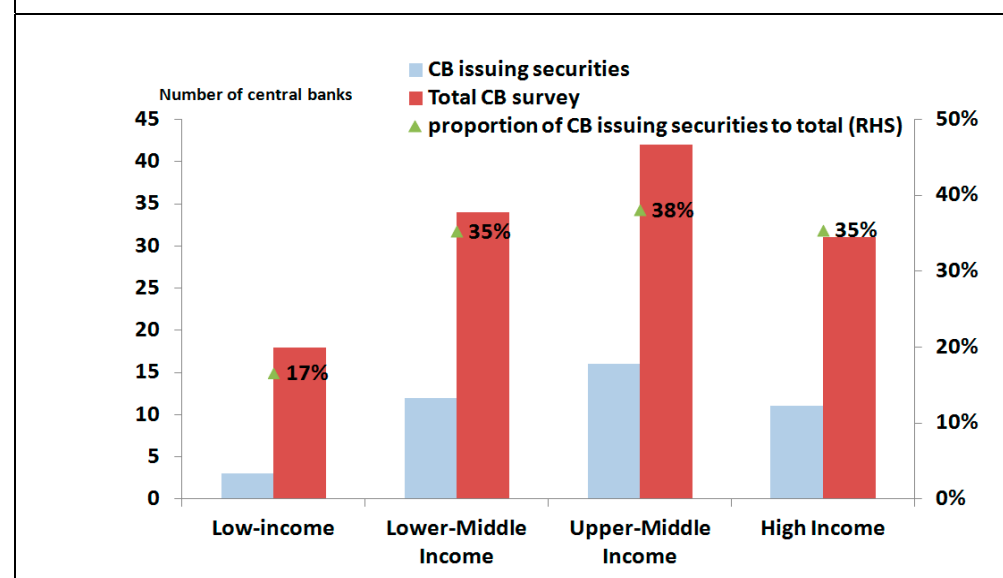

Source: Source: ISIMP and authors' calculations. financial sector is not an important player-or if the secondary securities market is illiquid, there may initially be less distinction between term deposits and CB securities. ${ }^{9}$ However, a key benefit of securities (or repo and FX swaps) over term deposits is that they allow the possibility of market development.

\section{The monetary policy} regime may also play an important role in determining whether CBs issue securities. Compared to other monetary policy regimes, CBs that have adopted inflation targeting (IT) are more likely to issue their own securities (Figure 4). Generally, most countries with an IT framework use a short-term interest rate as the operational target. In cases where reserve

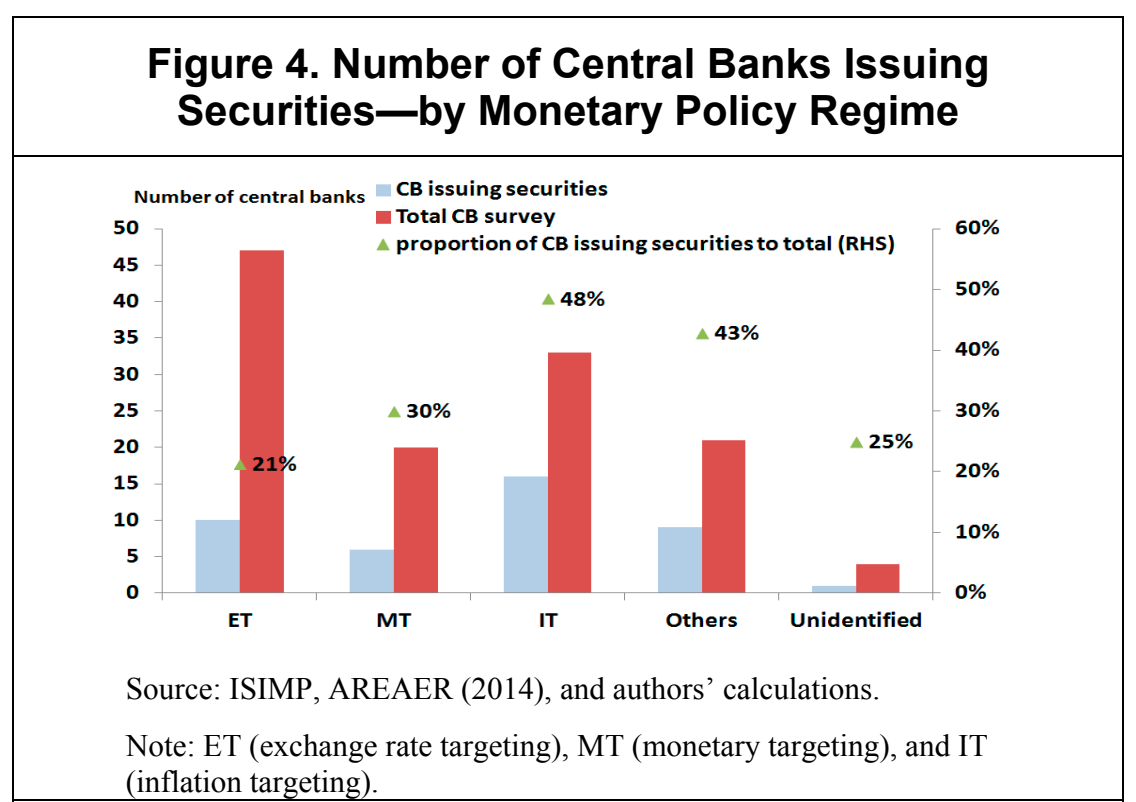

\footnotetext{
${ }^{9}$ Term deposits are generally non-tradable. If the securities market is illiquid, central bank securities cannot be
traded easily (i.e., close to non-tradable). Therefore, there is less distinction or advantage in issuing central bank

${ }^{9}$ Term deposits are generally non-tradable. If the securities market is illiquid, central bank securities cannot be
traded easily (i.e., close to non-tradable). Therefore, there is less distinction or advantage in issuing central bank securities over term deposits.
} 
balances are too large, the need to keep market rates close to the policy target requires having an effective OMO instrument, such as $\mathrm{CB}$ securities. ${ }^{10}$ On the other hand, under exchange rate targeting, the operational target would be the exchange rate itself, and more volatility in interest rates can be tolerated. In the case of monetary aggregate targeting, one might expect to see less financial market development, and less developed market-based monetary instruments.

\section{B. Why Do Central Banks Issue Securities?}

\section{CB legislation allowing the issuance of securities \\ is a necessary but not sufficient condition. Based} on the International Monetary Fund's Central Bank Legislation database (2013), most CBs are allowed by law to issue securities (74 percent of total). Out of those permitted, just over half (55 percent of that subset) do so. Clearly, other nonlegislative factors (including of course whether or not there is a need to drain surplus reserves) govern the decision to issue securities (Figure 5).

\section{Liquidity management purpose}

\section{CB securities clearly have a liquidity management function-particularly, to absorb} excess reserves. While the degree of excess reserves can be difficult to gauge, securitiesissuing CBs tend to have a bigger balance sheet as a percent of GDP_-suggesting an underlying need. Analysis of CB balance sheets is constrained by data availability and inconsistencies in item classifications, rendering cross-country comparison difficult. As noted earlier, the sources of surplus reserves in the system generally are monetary financing of the government, purchase of FX reserves, or possibly liquidity support provided to some banks. ${ }^{11}$ These actions tend to expand the asset side of the CB's balance sheet; and part of the

\footnotetext{
${ }^{10}$ There are exceptions to this - for instance, if the central bank is operating under a 'floor' system, where it could remunerate excess or total reserves to influence short-term market rates.

${ }^{11}$ If some banks in the market are perceived as weak, the central bank may have provided liquidity support to these banks, but the reserves thus created tend to migrate to the stronger banks. The central bank's balance sheet thus expands, as it intermediates part of the market.
} 
corresponding increase in liabilities may be securities issuance. Figure 6 provides some support to this argument (CBs issuing securities are highlighted in red).

\section{Figure 6. Size of Central Bank Balance Sheet (in percent of GDP) (as of 2013)}

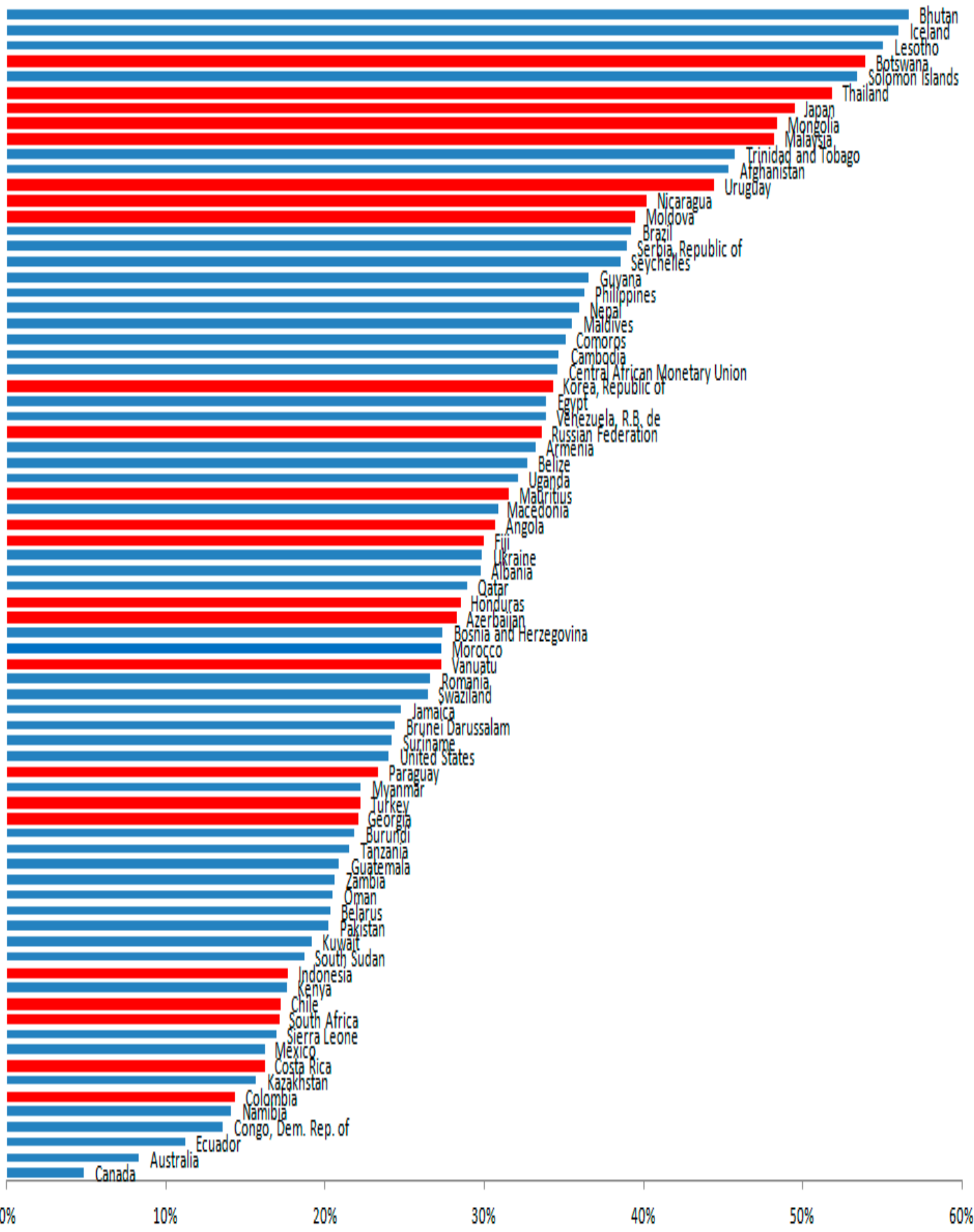

Source: International Financial Statistics and authors' calculations. 
Figure 7. Use of Other Liquidity Management Tools

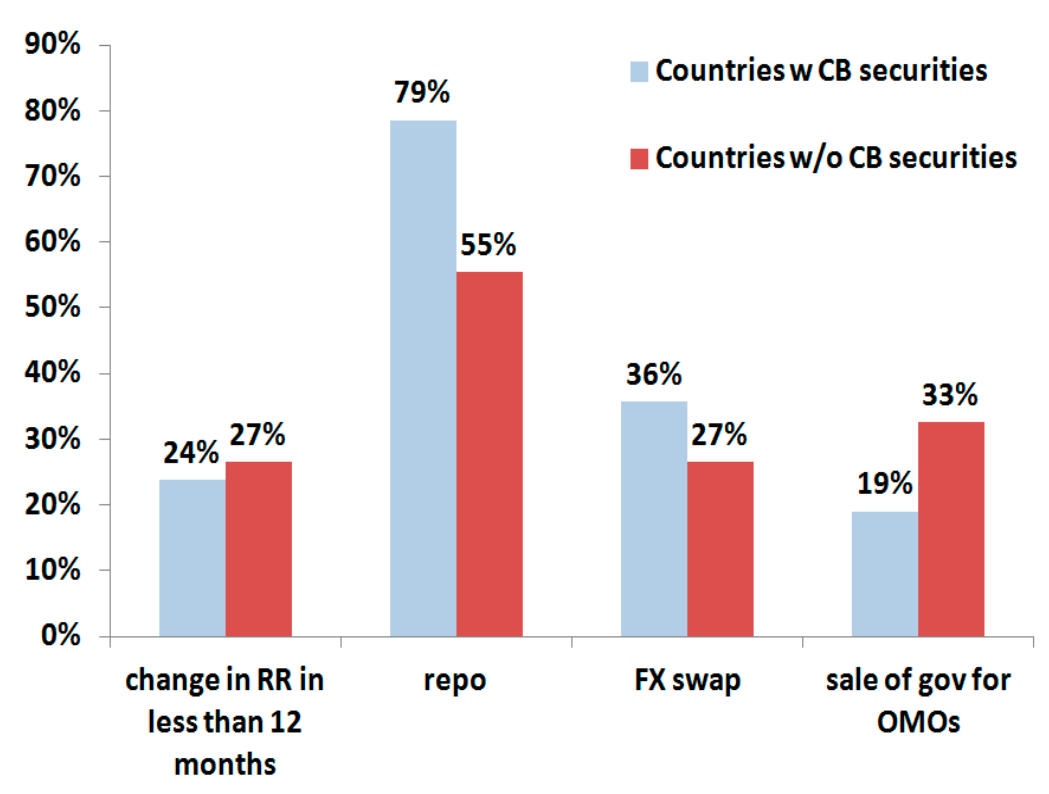

Source: ISIMP and authors' calculations.

\section{CB securities} generally serve as substitutes for reserve requirements or the use of government securities in OMOs to manage liquidity, but complement other market-based OMO tools. Figure 7 compares the use of other liquidity management tools among CBs issuing their own securities and those that do not. Those which do not issue $\mathrm{CB}$ securities are more likely to use government securities issuance to support liquidity management, or vary reserve requirements. Meanwhile, $\mathrm{CB}$ securities tend to be used to complement market-based instruments, i.e., repo and FX swaps. CB securities are not used as substitutes for very shortterm sterilization tools (such as overnight repo or swaps, or overnight deposits) which are

\section{Figure 8. Yield Spread and Central Bank Securities Issuance}

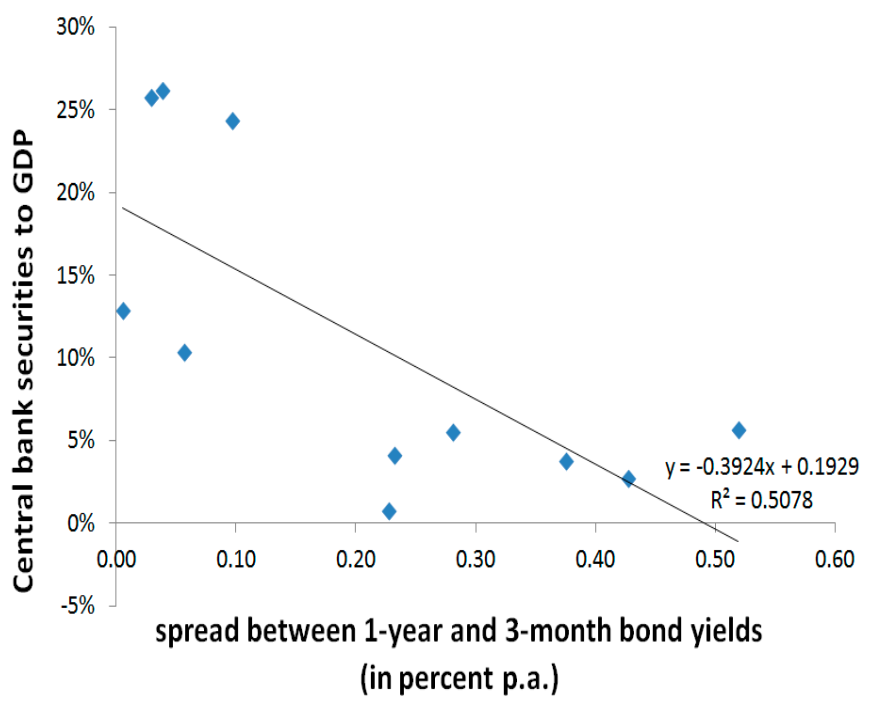

Source: ISIMP and authors' calculations. 
generally used to fine-tune liquidity and which, in many cases, transmit the monetary policy signal. ${ }^{12}$ The reasons for this are that the administrative costs of securities issuance may not be justified for very short-term operations and the benefits to the market of tradability are much less significant for short-maturity instruments. (That said, there are a few CBs that use short-term CB securities to transmit the policy signal, e.g., Sweden and Poland.) CB securities are more likely to be used to deal with longer term/structural excess liquidity, and thus tend to have longer maturities than other OMO reserve-draining instruments.

The choice of tools to conduct OMO is also influenced by the shape of the yield curvethe flatter the yield curve, the more likely the CB will use long-term OMO, and thus issue securities. Figure 8 shows the relationship between the volume of CB securities outstanding and the spread between 3-month and 1-year benchmark yields for a sample of 11 countries (as of July 2014). According to the figure, the lower the spread (i.e., the flatter the yield curve), the more securities CBs will issue. A flatter yield curve makes it more attractive for the $\mathrm{CB}$ to issue longer term instruments since it may be expected that the costs of longer term sterilization are not substantial. It may also be that commercial banks are more willing to accept longer term fixed interest rates when the yield curve is more stable, as they will then be less exposed to risk.

\section{Market development}

Besides liquidity management, some CBs also design their securities issuance program with the objective of fostering the development of the domestic bond market. Examples of these CBs are the Hong Kong Monetary Authority (HKMA), the Bank of Korea (BOK), and the Bank of Thailand (BOT). The HKMA issued 91-day to 15-year Exchange Fund Bills and Notes to establish the yield curve. The BOK and the BOT issue securities up to 2-year and 3-year maturities respectively to facilitate the construction of a benchmark yield curve at the short end, while avoiding overlap with (longer term) government securities issuance. Gray et al. (2013) noted that some CBs issue securities for other purposes. For instance, in 1997, Bank Negara Malaysia (BNM) issued securities to raise funding for bank recapitalization. Also, the Bank of England (BOE) has at times issued FX securities to fund its FX reserves.

\section{HOW DO CENTRAL BANKS ISSUE SECURITIES?}

This section explores practical issues pertinent to the issuance of $\mathrm{CB}$ securities. It considers whether treasury bills or CB securities should be used for liquidity management; and if CB securities are issued:

\footnotetext{
${ }^{12}$ Short-term instruments are often used at or around the central bank's target policy rate, while longer term instruments are more likely to be at market rates.
} 
- At what maturities should they be issued?

- Who should be the counterparties?

- Should the CB use a single-price or multiple-price auction?

- Should the CB retain discretion in its allocation?

- What type of securities should be issued?

The discussion of these issues will incorporate the findings of three case studies (Chile, Korea, and Thailand): further details could be found in Annex II. The CBs of these three countries are major issuers of securities of different types. Drawing on their experience could facilitate the design of products and provide suggestions on how to simultaneously achieve several objectives of central bank securities issuance.

\section{A. Treasury or Central Bank Bills for Liquidity Management?}

The choice between using government or CB securities entails a trade-off between cost and autonomy. If the costs of draining surplus liquidity are such that they will result in a continuing loss for the $\mathrm{CB}$, there is a clear case for making it a fiscal operation from the outset. ${ }^{13}$ If government securities are issued, and the reserve money thus drained is held in a blocked, non-interest bearing account at the $\mathrm{CB}$, then the costs are borne directly by the budget. However, few governments are prepared to take on this cost directly, or to give the $\mathrm{CB}$ full discretion in the issuance of such securities. Moreover, if liquidity management by the $\mathrm{CB}$ has to rely on regular requests to the government to issue securities, the CB's operational autonomy might be compromised. ${ }^{14}$

In practice, there are relatively few cases where government securities are issued to support liquidity draining operations. For example, when the market in India had a structural surplus of reserve balances (until 2011), the Reserve Bank of India (RBI), ${ }_{15}^{15}$ as an agent for the government, regularly auctioned treasury bills and cash management bills both to meet the government's short-term expenditure need and drain liquidity from the system. For the portion of securities used for liquidity absorption, the auction proceeds were kept in a Market Stabilization Scheme Account. The government, in collaboration with RBI, set the ceiling for issuance of these securities. (Since 2011, the market has moved to a structural deficit of reserves, removing the need to drain).

\footnotetext{
${ }^{13}$ In the long-term, central bank losses represent a fiscal cost, as the government will need to bear the costs of central bank recapitalization, instead of receiving dividends from the central bank.

${ }^{14}$ A fuller discussion on the issue of government or central bank securities can be found in Nyawata (2012) and Quintyn (1994).

${ }^{15}$ By legislation, RBI could not issue its own securities.
} 


\section{B. Central Bank Securities Issuance: Operational Issues}

\section{Maturity}

\section{CB securities usually cover the shorter segment of the yield curve. Based on a sample of 24 countries $^{16}$, as of end-July 2014, residual maturities of $\mathrm{CB}$ securities range from four days (Azerbaijan) to 5 years (Chile) with a mode of around one month (Figure 9). Unless there is a persistent structural excess liquidity, short}

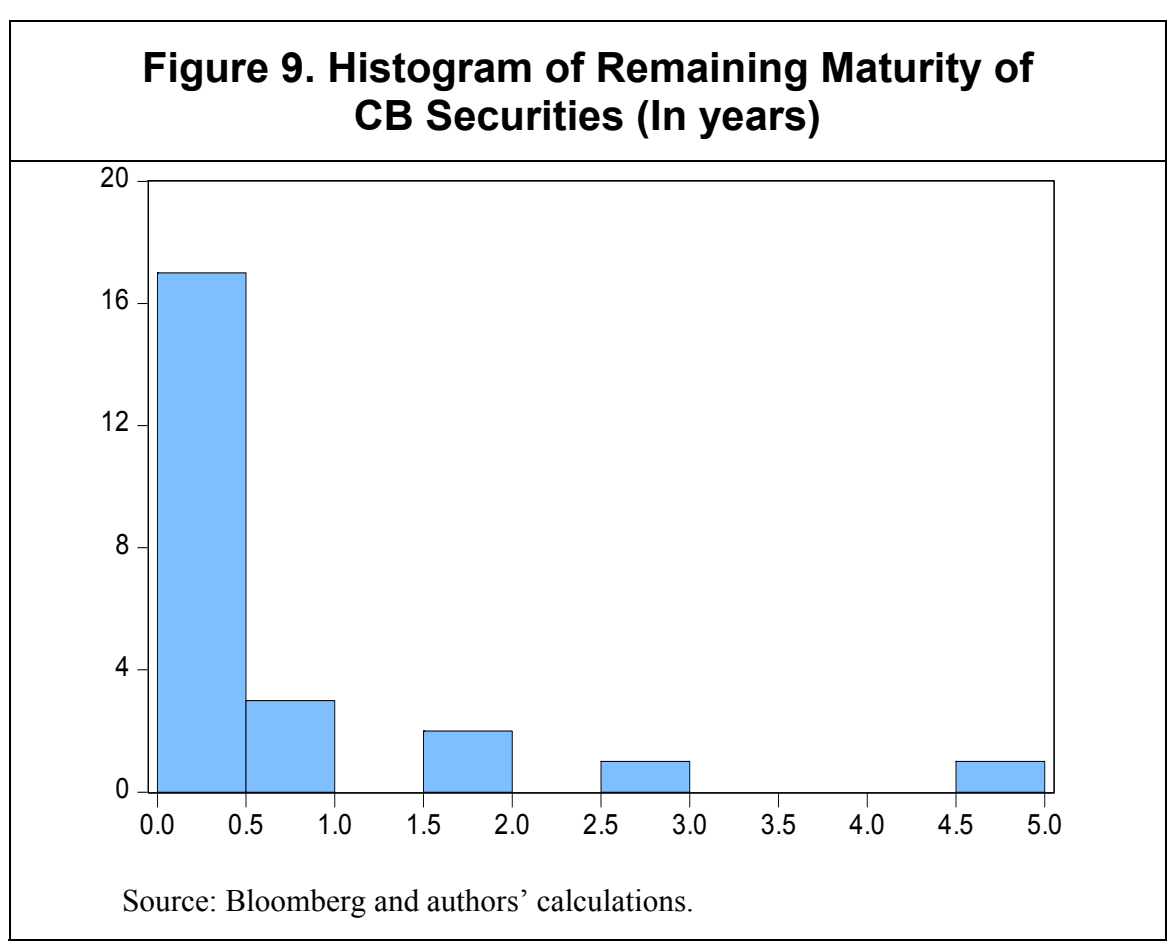
maturities may be preferred to allow more flexibility in unwinding the liquidity drain. ${ }^{17}$ Moreover, as indicated earlier, if the yield curve is steeply sloped, the CB is more likely to use shorter maturity instruments.

\section{Structural excess liquidity may call for longer term CB bonds to reduce the need for} frequent roll-overs. Clearly, if the banking system is awash with excess reserves, longer maturities have benefits for operational reasons, reducing the need for frequent roll-over of OMOs, as well as market development. If there is a sufficiently large demand for longer term paper, liquidity absorption through longer term bond issuance could smooth sterilization costs over a longer horizon - especially in the upward cycle of interest rates. For example, the CBs of Chile, Korea and Thailand issue their own securities of up to 20-year (indexlinked), 2-year, and 3-year maturities respectively.

\footnotetext{
${ }^{16}$ The sample was determined by data availability on central bank securities issuance; it includes Argentina, Azerbaijan, Botswana, Chile, China, Czech Republic, Dominican Republic, Georgia, Indonesia, Iraq, Republic of Korea, Kuwait, Malaysia, Mauritius, Mexico, Moldova, Namibia, Nigeria, Paraguay, Qatar, Singapore, Thailand, Uruguay, and Vietnam.

${ }^{17}$ At the same time, short-maturity central bank securities could also facilitate commercial banks' short-term liquidity management, especially in the case where bond markets are less liquid.
} 


\section{Longer maturity bonds may help develop a benchmark yield curve, if there is} insufficient supply of government bonds. In some cases, the government may be subject to strict fiscal discipline (which imposes a cap on the amount of securities it can issue), or may be running a surplus. As a result, the supply of sovereign bonds in the market may not be sufficient to facilitate construction of a benchmark yield curve. In such a case, the CB may step in and fill in the gap of missing supply by offering CB securities of longer maturity provided of course that there is a need to drain surplus reserves. A good example was the case of Chile before 2003, where there was large structural excess liquidity and insufficient bond issuance by the government.

\section{Coordination with the government debt management unit is crucial to ensure that} aggregate issuance of both $C B$ and government securities is consistent and meets the market's demand. Given a similar (sovereign) credit rating, the CB should coordinate with the government in designing its issuance plan to avoid confusing the market. If possible, both issuers should plan their issuance in a consistent manner to match the market's preference in terms of portfolio structure, particularly if the market has a strong 'preferred habitat'. For example, in situations where the government plans to raise funds by issuing domestic bonds at maturities of, say, 3-20 years, the CB should issue securities at maturities of less than 3 years to fill in the gap in the market's demand for shorter term instruments. ${ }^{18}$ The CB could also complement the government's issuance at the same maturities, if the supply of government securities at those maturities is insufficient. Together, both sovereign issuers will facilitate the construction of the benchmark yield curve.

In general the government should be given priority in bond issuance. Government bond issuance is an important source of funding for infrastructure and long-term projects, and more generally for meeting the government's financing needs. Alternative sources of funds, such as bank loans, are less advisable and more costly. The government's financing needs must be met regardless of whether there is a structural surplus or deficit of reserve money. Moreover, the $\mathrm{CB}$ has to be involved in draining reserves only when there is surplus; if the government's debt issuance drains all surplus reserves, then there is no need for the CB to issue anything. ${ }^{19}$ This points to the need to forecast liquidity accurately and to coordinate timing. For instance, if the CB forecasts surplus liquidity this week, but a balance or a shortage from next week following planned government debt issuance; it would not make sense for the $\mathrm{CB}$ to issue a 3 month bill to drain the surplus.

\footnotetext{
${ }^{18}$ Although over time, aging of the outstanding stock will mean there are government securities with residual maturities that overlap with those of the central bank.

${ }^{19}$ If a government meets its financing needs by borrowing in foreign currency, selling the FX to the central bank and then spending domestic currency, the central bank may need to drain the consequent surplus of reserves. Some governments have decided that it is more efficient (and overall cheaper) for the government to switch its borrowing to the domestic market.
} 


\section{Counterparties}

There are different approaches to the choice of counterparties to the issuance: broad participation provides more competition and better pricing but could increase administrative costs. ${ }^{20}$ Competitive bidding tends to drive up bond prices, and therefore helps reduce interest costs for issuers. However, if the auction system is not automated, broad participation (which includes non-banks) will increase processing costs and may cause problems to the payment and settlement system. High administrative costs and potential problems to the payment and settlement system may dissuade the CB from allowing broader participation.

At the same time, transmission of monetary policy may be more effective with larger group of participants. If there is insufficient competition in the banking system - and often a substantial structural surplus of reserves is associated with reduced competition - then the interest rate paid by the $\mathrm{CB}$ on securities (or other reserves draining instruments) may not be transmitted through to the rest of the economy as effectively. In such cases, the costs of permitting broader participation may be more than offset by the increase in monetary policy efficiency.

It is important to distinguish between restrictions on participation in the auction, on the one hand, and on ownership, both direct and indirect, on the other. A CB could restrict bidding to banks only; or restrict bidding to banks but allow them to bid on behalf of customers (though this may complicate rules on maximum allotment per bidder). If only banks are allowed to bid, secondary market trades could be restricted to banks (i.e., only banks would be allowed to own CB securities); or it could involve other institutional investors. In the latter case, provision would need to be made for those investors to have securities accounts with the depository (often the CB itself is the depository for its own bills), with the ability to use their holdings in transactions — whether selling outright, pledging or using in repo.

Maximum and minimum limits may be set on individual bids to avoid market cornering and discourage a large number of small bids. Ceilings for bids are typically set in the range of 20-30 percent; but they are not uniformly used. ${ }^{21}$ Market cornering is less of a concern with short-term securities which are issued frequently, but more important for securities with maturities of 6 months or longer. Moreover, any ceiling must take account of the relative size of participants: such restrictions should not make it impossible for participants to able to bid for all the securities on offer. Minimum bid sizes are used to prevent a large number of small (retail) bids, which may add little value to the CB's goals.

\footnotetext{
${ }^{20}$ Out of 42 central banks that were reported issuing securities, 11 auction securities only to commercial banks while the rest have a wider group of counterparties.

${ }^{21}$ Turner (2002)
} 
Some countries also use non-competitive bids. A pre-determined amount of securities may be allocated at the weighted average price of successful bids, to expand the investor base and facilitate access by less sophisticated/less well-informed players.

\section{Type of auction}

There are two main types of auctions: multiple price and single price. A multiple price auction is where each successful bidder pays the price they bid. In a single (or common, or uniform) price auction, all successful bidders pay the lowest successful price bid i.e., the cutoff price. Table 1 shows that CBs use both types of auctions.

In addition to multiple-and single-price, a few CBs use fixed price auctions when they use their securities to transmit a monetary policy signal. For instance, the Riksbank (CB of Sweden) issues Certificates at the same interest rate as the repo rate (the policy rate). Also, the National Bank of Poland (NBP) issues 7-day CB bills on a regular basis, the yields of which are determined at the level of NBP reference rate.

Table 1. Examples of Central Bank Securities Issuance

\begin{tabular}{|c|c|c|c|}
\hline Country & $\begin{array}{c}\text { Curve Span } \\
\text { (Common Tenors) } \\
D-\text { Day; W-Week; } M-\text { Month; } \\
\text { Y-Year }\end{array}$ & Auction Style & $\begin{array}{c}\text { Restrictions on } \\
\text { Ownership* }\end{array}$ \\
\hline Angola & $14,28,63$, and 182 Days & Multiple-price & Yes \\
\hline China & $\begin{array}{c}3 \mathrm{M}-3 \mathrm{Y} \\
(3 \mathrm{M}, 6 \mathrm{M}, 1 \mathrm{Y})\end{array}$ & Single-price & No \\
\hline Costa Rica & $1 \mathrm{Y}-15 \mathrm{Y}$ & Multiple-price & Yes \\
\hline $\begin{array}{l}\text { Dominican } \\
\text { Republic }\end{array}$ & $1 \mathrm{M}-7 \mathrm{Y}$ & Multiple-price & No \\
\hline Indonesia & $9 M$ & Multiple-price & No \\
\hline Malaysia & $\begin{array}{l}\text { Up to } 1 Y \\
(3 M, 6 M)\end{array}$ & Multiple-price & No \\
\hline Peru & $2 M-1 Y$ & Multiple-price & Yes \\
\hline Singapore & $\begin{array}{c}\text { Up to } 3 \mathrm{M} \\
(4,6,8 \text { Weeks, up to } 3 \mathrm{M})\end{array}$ & Single-price & No \\
\hline $\begin{array}{l}\text { South Korea } \\
\text { (BOK: MSB) }\end{array}$ & $\begin{array}{c}1 \mathrm{M}-2 \mathrm{Y} \\
(1 \mathrm{M}, 3 \mathrm{M}, 1 \mathrm{Y} \text { and } 2 \mathrm{Y})\end{array}$ & Single-price & No \\
\hline $\begin{array}{l}\text { Taiwan, POC } \\
\text { (CBC: NCDs) }\end{array}$ & $\begin{array}{c}1 \mathrm{M}-24 \mathrm{M} \\
(30,91,182,364 \text { Days })\end{array}$ & $\begin{array}{l}\text { Multiple-price for 364D, } \\
\text { Single-price for the rest }\end{array}$ & N/A \\
\hline Thailand & $\begin{array}{c}14 \mathrm{D}-3 \mathrm{Y} \\
(3 \mathrm{M}, 6 \mathrm{M}, 1 \mathrm{Y})\end{array}$ & Multiple-price & No \\
\hline Vietnam & $\begin{array}{c}1 \mathrm{~W}, 2 \mathrm{~W}, 1 \mathrm{M}, 2 \mathrm{M}, 3 \mathrm{M}, 6 \mathrm{M}, 1 \mathrm{Y} \\
(3 \mathrm{M}, 6 \mathrm{M}, 1 \mathrm{Y})\end{array}$ & Single-price & N/A \\
\hline
\end{tabular}

Source: Gray et al. (2013), Local Market Compendium 2014, Standard Chartered Bank;

ISIMP database (2013); national CBs. Information as of 2013.

$* \mathrm{~N} / \mathrm{A}$ - Information is not available 


\begin{abstract}
A multiple price auction may help reduce overall sterilization costs and encourage competitive bidding, but could create a 'winner's curse.' As every successful bidder pays the price(s) they bid, the CB may be able to sell its securities at a higher average price (i.e., at lower interest costs), compared to single price bidding. In addition, multiple price auctions should encourage competitive bidding and help lessen the possibility of manipulation. However, bidders who pay higher prices than the cut-off price could make a loss, assuming the secondary market trading following the auction starts at the cut-off price. This "winners' curse" could lead participants to bid a lower price than would otherwise be the case, leading to a lower price on average for subsequent auctions.
\end{abstract}

The maturity of securities being auctioned, and the market structure, should influence the choice of auction structure. In cases of short-term securities where the CB is guiding the price, or where it is important to facilitate wide participation, a single price system may best support the goals. Indeed, since one of the goals of CB securities issuance is to prevent short-term market yields falling too low, the CB's primary goal here is clearly not to issue at least cost. ${ }^{22}$ In the case of longer term securities, price formation may be more important, and a multiple price system may motivate participants to gather information and support price formation.

\title{
Types of securities
}

CB securities are generally issued at a discount or with a fixed coupon. Unless the CBs are major issuers of securities alongside the government, the total issuance volume is limited. For that reason, CB securities are usually of standard types, i.e., discount or fixed-coupon bonds. A few CBs have issued index-linked or floating coupon bonds, particularly at longer maturities. In Chile, for example, the CB issues inflation-indexed bonds. In the case of Thailand, floating coupon bonds (linked to the Bangkok Interbank Offered Rate (BIBOR)) have been issued on a regular basis.

\section{CBs may issue saving bonds for retail investors, but this type of bond generally lacks} liquidity. Saving bonds for retail investors were issued by the BOT and Bank Negara Malaysia. Such issuance was aimed to provide alternative instruments for households and, at the same time, absorb liquidity. Nonetheless, retail saving bonds are usually small in volume and generate large administrative costs. They cannot be used as a main liquidity absorption channel, or for fine tuning. Furthermore, saving bonds are not usually traded, and trading may not even be permitted. Retail bonds are likely to be issued to compete with commercial bank term deposits and thus increase the effectiveness of transmission mechanism by enhancing competition (where it is insufficient). This would include the case where deposit rates may be deemed too low for a given level of CB policy rates.

\footnotetext{
${ }^{22}$ A government issuing securities to finance its deficit typically aims to issue at least cost, with least risk, over a period of time. The central bank's goals are different.
} 


\section{Some General Guidelines}

Some general guidelines can be provided on the four major building blocks of the issuance of CB securities: the allocation of OMO instruments; planning the issuance of CB securities; the auction itself; and post-auction assessment. These draw on the case studies, on the lessons from numerous technical assistance missions, and on the preceding discussion.

\section{A. The Allocation of Open Market Operation Instruments}

The allocation of liquidity management instruments needs to take into account the structure of future liquidity flows, which would require forecasts. A separation between short-term changes and long-term changes should be forecasted in order to plan an appropriate allocation of different instruments. CBs need to develop a medium-term forecast of their balance sheet (the so-called 'autonomous factors ${ }^{23}$ ). The short-term (cyclical) component of liquidity may be dealt with through shorter term OMO instruments such as reverse repo or deposit auctions while a longer term/structural liquidity surplus could be absorbed by CB securities.

\section{The distribution of} maturities among various instruments should be related to the different segments of instrument demand. For instance, fine-tuning operations such as reverse repo

\begin{tabular}{|c|c|}
\hline \multicolumn{2}{|c|}{$\begin{array}{l}\text { Table 2. Examples of Maturity Ranges by Liquidity } \\
\text { Management Instruments }\end{array}$} \\
\hline Instrument & Range of Maturity \\
\hline Deposit/Lending Facilities & Overnight \\
\hline Term Deposit/Collateralized Loan & 1 day, 7 days, 14 days, 1 month \\
\hline Repo/Reverse repo & 1 day, 7 days, 14 days, 1 month \\
\hline FX Swap & Overnight -12 months \\
\hline CB securities & 3 months onwards \\
\hline
\end{tabular}
might stretch from overnight to 1 month while CB securities would extend from 3 months onwards. If there are restrictions on access to the different instruments (for instance, only commercial banks could place term deposits or undertake repo transactions with the $\mathrm{CB}$, but $\mathrm{CB}$ securities are available to all) there might be a case for having different OMO instruments with overlapping maturities. While all instruments would serve the ultimate goal of liquidity management, consideration could be given to the secondary objective, such as construction of a benchmark yield curve, or repo and swap market development, or strengthening the transmission mechanism by creating more competition. Table 2 shows an example of maturity range by different instruments.

Monthly liquidity forecasts are generally needed. Securities issuance, unlike short-term fine-tuning instruments such as repo, requires longer term liquidity planning both by the CB

\footnotetext{
${ }^{23}$ The autonomous factors (or factors that drive central bank's balance sheet, therefore, affect overall liquidity in the system) are primarily: changes in demand for currency in circulation; changes in net FX reserves; and changes in government balances.
} 
and market participants. An auction schedule should be announced well in advance to allow time for market participants to plan. Doing this requires longer term (longer than one day or one week) liquidity forecast to gauge how much liquidity is to be absorbed by the overall issuance. Once longer term liquidity management needs are identified, fine-tuning instruments will help absorb shorter term swings in liquidity as well as remaining shortfall/surplus of liquidity resulting from uncertainties and forecast errors. At the shorter end of liquidity management operations, higher frequency liquidity forecasts (such as daily or weekly) would be required in line with the OMO cycles. For instance, if the repo is conducted on a daily basis, a daily liquidity forecast would be needed.

\section{B. Planning the Issuance of Central Bank Securities}

\section{Assessing market conditions and the government bond issuance plan}

Liquidity conditions, government bond supply, and secondary objectives of issuance are important supply - side determinants of the total amount and distribution across different maturities of $\mathbf{C B}$ securities. The amount of longer term surplus liquidity in the system partly governs the target amount of issuance. However, as discussed in Section III, the amount of CB securities issuance and its maturity profile should be part of a coordinated plan of overall sovereign securities issuance, and be designed in such a way that it could also serve other purposes of issuance.

On the demand side, bond market conditions have to be assessed before planning the issuance. The volume of issuance at a given maturity may be adjusted to accommodate changes in demand. For example, a market rally and capital inflows could generate strong demand for securities in general, while expectations of QE tapering in other countries could soften the demand. ${ }^{24}$ In addition, different types of investors typically demand different products. For example, commercial banks would generally buy shorter term or floating rate securities while pension funds and insurance companies would tend to invest in longer term bonds.

\section{Auction announcement}

Once the volume and maturities have been decided, the $C B$ should announce the auction schedule, which could be done at different frequencies with differing details. While there may be uncertainty regarding the accuracy of the liquidity forecast and market conditions, pre-announced auction dates facilitate planning by market participants. A broad plan of issuance (in a range) covering the next year may be announced before the end of the year, while an exact (or a narrower range of) auction volume could be announced on a

\footnotetext{
${ }^{24}$ Financial stability considerations may also factor into the plan of issuance. For example, issuance of central bank securities could encourage further capital inflows, leading to further exchange rate intervention, which subsequently leads to an increasing need to absorb surplus liquidity at higher rates, and so further short-term capital inflows (a potentially vicious circle).
} 
monthly basis or closer to the auction date (at least a day before) to accommodate changing market conditions. To preserve credibility, the monthly auctioned volume should generally fall within the range announced. If they are vastly different, the CB might consider issuing a statement to explain changes in the plan. ${ }^{25}$

\section{If scheduled auction dates are consistent with redemptions and well-coordinated with} the government, it would help ease pressure on the payment system and avoid complicating liquidity management by auction participants. Generally, if periodical issuances of securities are planned, CBs may plan the settlement date to coincide with the date of redemption on securities of similar types. This way, the pressure on the payment system will be eased. This clearly means that scheduled auctions should be planned in coordination with the government's plans. Whether both the government's and CB's auctions should be on the same day will depend on the arrangements and the nature of both products. If, for example, government bonds are auctioned on certain days of the week, say Monday, the $\mathrm{CB}$ could avoid Mondays so as not to complicate liquidity management by auction participants - especially if maturities of bonds to be auctioned by both issuers are quite close - since participants in one auction will not know until after the auction whether their bid was successful (and therefore what residual needs they may have for securities). ${ }^{26}$ (See Figure 10 for the overall process of CB securities issuance).

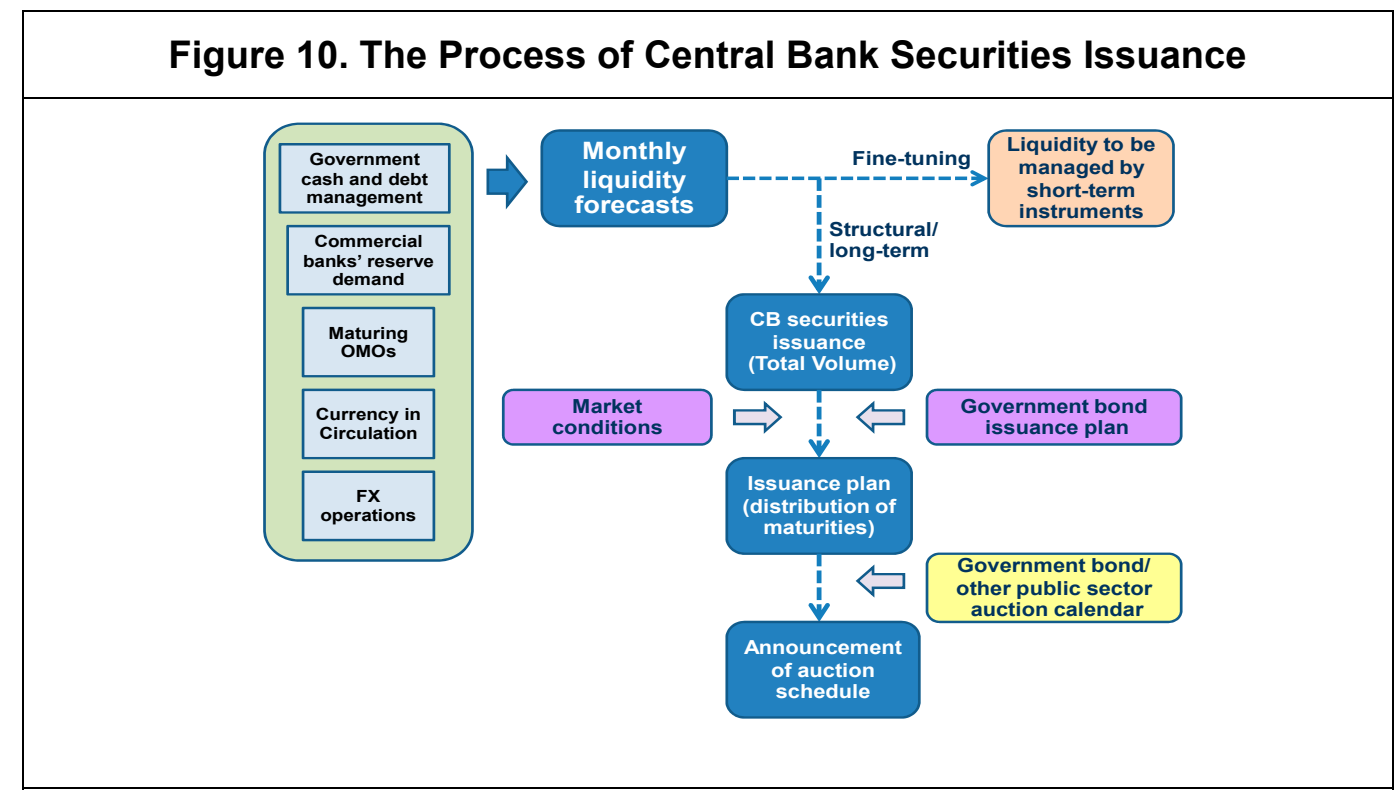

\footnotetext{
${ }^{25}$ See Annex III for an example of an annual issuance plan.

${ }^{26}$ For instance, if the results of the government bond auction were not known until after the bidding cut-off time for central bank bills, participants might not be sure how much liquidity they had available.
} 


\section{The Auction}

The decision on the cut-off price should follow a 'rules-based' or 'constraineddiscretion' approach. Under a rules-based approach, all bids up to full allotment are accepted, no matter what levels of interest rates are bid-i.e., "let the market speak". . Alternatively, the CB may practice a 'constrained discretion' following internal (or possibly published) guidelines - unconstrained discretion could cause large market uncertainty and volatility in securities prices.

CBs may retain discretion in the allotment of securities to eliminate extreme outliers. There could be a lot of uncertainties in the market conditions and the outturn of the auction may not be as expected/forecast. For these reasons it is useful that CBs retain discretion in the allotment of securities. On the underbid side, even if there is insufficient demand for bonds but the bidding has a very long tail (the spread between the cut-off price and the weighted-average accepted price) and there are clear outliers ${ }^{27}$, CBs may decide to underallot $\mathrm{CB}$ securities to avoid distortion in the yield curve. On the overbid side, CBs may implement an overallotment scheme, when certain conditions are met (such as high bid-tocoverage-ratio or limited range of min-max yields, etc.). ${ }^{28}$

The definition of outliers should be as rules-based as possible. By defining ex ante what constitute outliers (for instance, bids that deviate from the current market price or the majority of bids by $\mathrm{X}$ percent) decision-making is easier. Increased predictability supports market development. Outliers in a securities auction could either be bids at an interest rate that is too low (the price bid is very high) — though this is unlikely in the short-term to be a problem - or interest rates that are too high (the price bid is too low). One gauge of market prices could be the weighted average rate of bids above the cut-off point (before rejecting any outliers). A bid more than, say, Y percent away from this weighted average could be rejected as an outlier. Where the market price is reasonably certain, and the demand curve therefore, reasonably flat, it should be unlikely that any bid would be rejected.

Discretion should not be used to influence long-term market rates. Doing so would risk losing information content and distort future bidding by participants. As noted earlier, the reasons for issuing $\mathrm{CB}$ securities should be to manage liquidity conditions in order to influence the short-term rate, or to drain a structural surplus at a market rate. Generally, CBs should refrain from influencing long-term rates unless there are market anomalies, or where there is a clear intention to do so under QE. Any decision to eliminate extreme outliers or over-allot should be done in such a way as to avoid an impact on underlying market yields. The general guidelines on the use of such discretion may be communicated to the market to

\footnotetext{
${ }^{27}$ For example, the bids that differ from the average by more than $\mathrm{X}$ bps, where $\mathrm{X}$ depends on the structure of that particular market-to be determined by the central bank.

${ }^{28}$ The central bank could indicate a maximum 'overallotment' e.g., 20 percent of the amount on offer.
} 
help reduce uncertainties. Doing so will help strike a balance between extracting information content from the market and avoiding volatility in the yields.

Generally, auction results should be announced within half an hour to an hour of the auction to allow the market sufficient time to access secondary market or other finetuning operations. While it may take time to finalize an auction, especially if discretion is exercised, the CB should announce the results fairly quickly. This would allow market participants, especially those who are unsuccessful, to find alternative investment channelsbe it in the secondary bond market or other fine-tuning operations. In any case, market activity is likely to be muted until the auction results are announced and it can be damaging to keep markets in suspense for a prolonged period.

Auction results should be announced in aggregate with a set of standard outcomes. Following the auction, each market participant should be informed directly whether their bid is successful. In contrast, public announcement of the results of the auction - at the same time that successful participants are informed - should refer to aggregate figures, including bidding volume, amount allocated, bid-coverage ratio and the cutoff price. In addition, publishing the weighted average price of successful bids is very helpful to the market, as the difference between this weighted average and the cut-off price gives a good indication of the spread of prices bid, and thus the slope of the demand curve.

\section{Post-auction Assessment}

The CB should use the auction results to gauge market conditions. This can help in planning the next round of issuance. Bidding volume, bid-cover ratio and rates provide indicators for primary market conditions, which would then have knock-on effects on the secondary market and thus the yield curve. This information also helps the CB adjust its strategy and tactics in line with the market conditions.

Analysis of auction results should be considered within an overall framework of liquidity management. $C B$ securities are only one out of many liquidity management tools. While preferences over different instruments may differ, bids that largely under or overshoot expectations may reflect inaccuracies in liquidity forecasting, disruption in market conditions or the overall liquidity conditions. By attempting to understand the underlying causes, the overall liquidity management plan could be improved, paving way for increasingly effective liquidity management.

\section{Conclusion}

CB securities are issued mainly to absorb excess liquidity, and complement other shortterm market-based liquidity management tools. Recipients of large capital inflows, such as some countries in Asia and Latin America, are more likely to issue CB securities due to the need to sterilize excess liquidity, and able to do so because of a sufficient level of market development. For most countries, CB securities are used to complement other market-based 
liquidity management tools such as repo and FX swap but tend to substitute for the use of reserve requirement or government securities.

The ISIMP survey also suggests that inflation targeting countries are more inclined to issue CB securities while low-income countries are least likely to issue them. Inflation targeting $\mathrm{CBs}$ would require active liquidity management to steer short-term market rates close to the policy target. $\mathrm{CB}$ securities can serve as an effective OMO tool in support this objective. On the other hand, the issuance of CB securities by low-income countries may be hindered by high administrative costs, or the lack of a supportive market infrastructure.

While the operational details of $\mathrm{CB}$ securities issuance differ across countries, the maturities of securities issued tend to concentrate at the shorter segment of the yield curve. There are of course exceptions especially in the case where excess liquidity is structural and there is insufficient government bond supply. Importantly, the plan of CB securities issuance should be closely coordinated with that of the government to ensure consistency and facilitate well-functioning and appropriate development of the sovereign domestic bond market.

The paper also provides some general guidelines on the four major building blocks of CB securities issuance. The guidelines encompass several important steps-from the planning stage (which includes for instance liquidity forecasting, allocation of OMO instruments and market assessment), auction process (whether and how to allow for discretion in the allocation of bids) and post-auction assessment. Drawing on international experiences, these steps provide CBs some guidance on best practices on the operational aspects of $\mathrm{CB}$ securities issuance. 


\section{REFERENCES}

Bank of Korea (2012), Monetary Policy in Korea.

Bank of Korea (2013), Financial Markets in Korea.

Bank of Thailand (2012), Monetary Policy Instruments, Bank of Thailand website (www.bot.or.th).

Central Bank of Chile (2012), Liability Management of the Central Bank of Chile.

Central Bank of Chile (2013), Annual Report 2013.

Filardo A., M. Mohanty and R. Moreno (2012), 'Central bank and government debt management: issues for monetary policy', BIS Papers No. 67, Bank for International Settlements.

Gray S., P. Karam, V. Meeyam, and M. Stubbe (2013), Monetary Issues in the Middle East and North Africa Region: A Policy Implementation Handbook for Central Bankers, International Monetary Fund.

IMF and World Bank (2001), Developing Government Bond Markets: A Handbook, The International Bank for Reconstruction and Development/The World Bank, International Monetary Fund.

IMF (2005), Financial Sector Assessment: A Handbook, International Monetary Fund.

IMF (2013), Unconventional Monetary Policies - Recent Experience and Prospects, April 18. http://www.imf.org/external/np/pp/eng/2013/041813a.pdf.

IMF (2014a), 'Emerging Market Volatility: Lessons from the Taper Tantrum', IMF Staff Discussion Note, September 2014.

IMF (2014b), Annual Report on Exchange Arrangements and Exchange Restrictions, International Monetary Fund. (AREAER).

Nyawata, O. (2012), 'Treasury bills and/or central bank bills for absorbing surplus liquidity: the main considerations', IMF Working Paper No. 12/40, International Monetary Fund.

Quintyn, M. (1994), 'Government Securities versus Central Bank Securities in Developing Open Market Operations - Evaluation and Need for Coordinating Arrangements', IMF Working Paper No. 94/62, International Monetary Fund.

Rule, G. (2011), 'Issuing central bank securities', CCBS Handbook no. 30, Bank of England.

Standard Chartered Bank (2013), Local Market Compendium 2014.

Turner, P. (2002), 'Bond markets in emerging economies: an overview of policy issues', $B I S$ Papers No. 11, Bank for International Settlements. 


\section{Annex I. List of Countries Included in ISIMP (2013)}

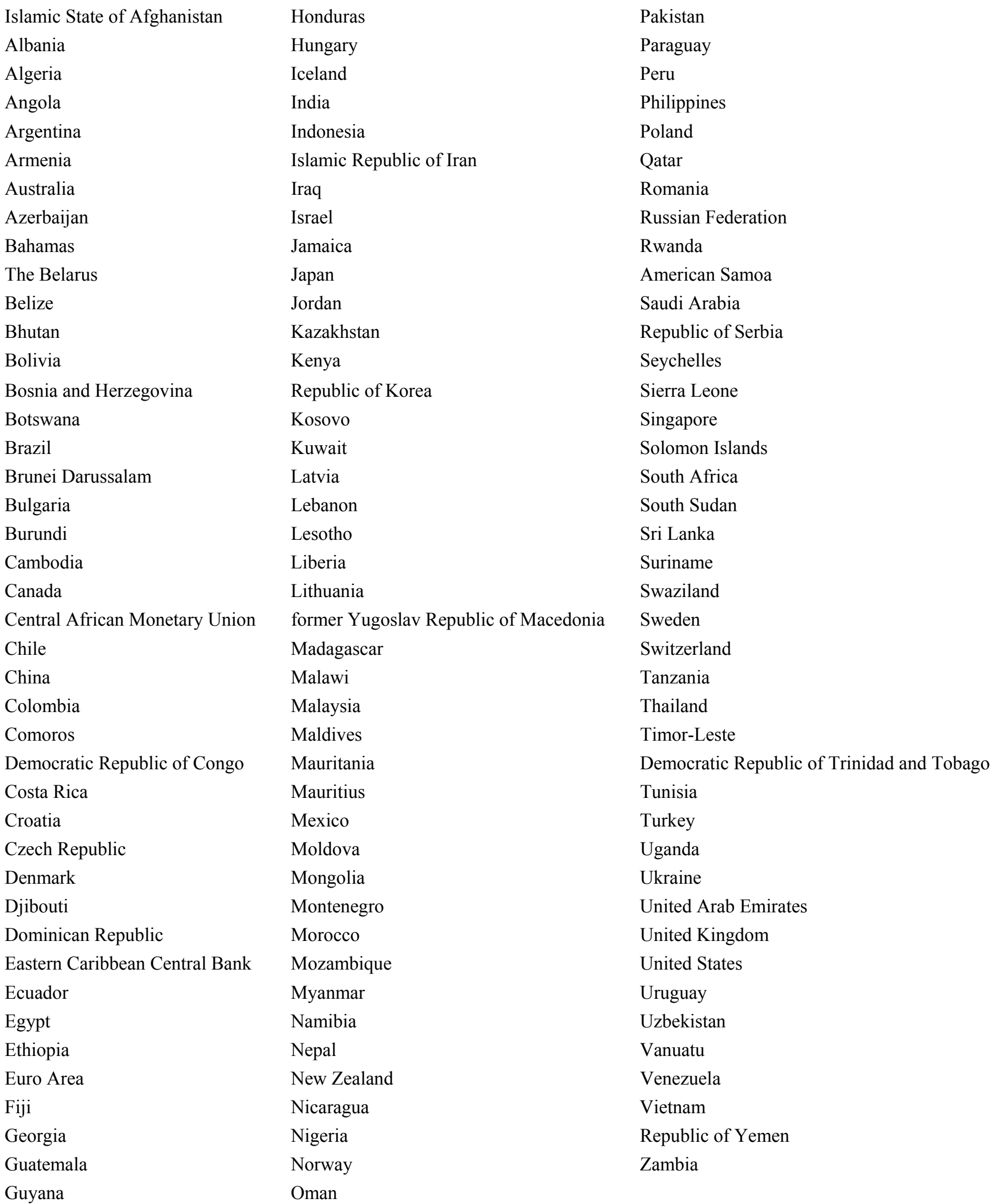




\section{Annex II. Central Bank Securities Issuance-Case Studies of Chile, Korea, and Thailand $^{29}$}

The central banks of Chile, Korea and Thailand are major issuers of CB securities. In each of these cases, the outstanding amount of CB securities and bonds issued exceeded 10 percent of GDP as of mid 2014. As a result, these CBs have become a major sovereign bond issuer alongside their government.

The three cases share some key features. In these countries, CB securities are generally used as a longer term instrument to absorb structural excess liquidity, often stemming from large increases in FX reserves. Large-scale issuances of CB securities allow those $\mathrm{CBs}$ to offer a variety of products, which helps facilitate bond market development (especially in the case where government bond issuance is constrained by fiscal discipline). The case studies also highlight the developmental role of both the government and CBs and the need for close coordination.

\section{A. Chile}

Issuance of CB debt securities in Chile was initially aimed at financing the rescue of the financial system and later to sterilize reserve accumulation. In the wake of the 1982-3 banking crisis, the Central Bank of Chile (CBC) issued bonds to finance the rescue of the financial system through liquidity provision and recapitalization of the banking system. During this time, the $\mathrm{CBC}$ did not have autonomy (granted at the end of 1980s) and acted on behalf of the fiscal authority. In the 1990s, the purpose of issuance changed. Chile adopted a target zone for the exchange rate, and large capital inflows prompted a rapid accumulation in FX reserves. This reserves accumulation was sterilized mainly through bond issuance. The reserves build-up episode returned in 2011, again calling for a large bond issuance program.

CBC issues promissory notes and bonds to address structural changes in the monetary base. Under its inflation targeting regime, $\mathrm{CBC}$ manages reserve balances to ensure that the overnight interbank rate is close to the monetary policy rate (MPR). CBC uses two types of OMOs-fine-tuning and structural. Repurchase agreements (repos) and deposits are mainly used as fine-tuning OMOs while issuance of notes and bonds is used to manage long-term (structural) changes in the monetary base.

Notes and bonds of various maturities have been issued both in pesos and UFs (inflation-indexed accounting unit). $\mathrm{CBC}$ issues discount promissory notes (PDBC) with maturities between 28 and 360 days, peso-denominated bonds (BCP) with 2-year, 5-year and ten-year maturities, and UFdenominated bonds (BCU) at maturities of 5, 10, and 20 years. Issuance of UF-denominated bonds is a legacy of historically high inflation, which explains the dominance of indexation.

Coordination with the government is crucial for bond market development. Over the past few decades, fiscal discipline has reduced the need for a large issuance of government securities. However, since 2003, the government started regular issuance of domestic bonds alongside the CB, to facilitate bond market development. Two types of government bonds have been issued - peso-denominated

\footnotetext{
${ }^{29}$ Primarily based on information from liability management of the Central Bank of Chile (2012), Central Bank of Chile Annual Report (2013), Filardo et. al. (2012), Financial Markets in Korea (2013), Monetary Policy in Korea (2012), the BOK, and BOT websites (www.bok.or.kr and www.bot.or.th) as of July 2014.
} 
bonds (BTP) and inflation-linked bonds (BTU). The primary objective of issuance is to build the long end of the yield curve-in coordination with the CB.

\section{B. Korea}

The first issuance of CB bonds in Korea dates back to 1961. Monetary Stabilization Bonds (MSBs) - the CB bonds - were issued from November 1961 as the first instrument for open market operations. Development of other OMO instruments followed with the start of purchases and sales of government and other public sector bonds from 1969 and repurchase agreements (RPs) in 1977. Regular issuance of MSBs started in January 2003.

At present, MSBs are used as a structural liquidity adjustment tool. Under its inflation targeting regime, the Bank of Korea (BOK) uses OMOs to keep the (unsecured overnight) call rate in line with the base rate set by the Monetary Policy Committee (MPC). Both short-term and long-term (structural) OMO instruments are used. The BOK uses repurchase operations and a term deposit (Monetary Stabilization Account, MSA) as the main short-term liquidity instruments, while MSB serve as a longterm liquidity adjustment tool.

Both discount and coupon bonds are issued at various maturities via two different types of auction; a ceiling on the issuance is set by the MPC. Discount bonds can be issued at a wide spectrum of maturities - from 14 days to 2 years, while coupon bonds are issued at 1-year, 1.5-year and 2-year maturities. The MPC decides on the issuance ceiling on a quarterly basis. Public offering of MSBs employs both subscription method and competitive auction. In the competitive auction, MSBs are allocated according to bid rates, using a single-rate method. Only 91-day, 182-day, 1-year and 2 -year MSBs are issued regularly via competitive bidding. The subscription method, using a fixed interest rate, applies to the fungible issue of 1-year and 2-year MSBs.

To help increase liquidity in the secondary market, the BOK introduced a buy-back scheme for MSBs. BOK repurchases 2-year MSBs with remaining 3-,5-,7- and, 9-month maturities twice in every odd month. Together with the fungible issuance, this has helped increase liquidity in the secondary market.

\section{Thailand}

Since 2003, the Bank of Thailand (BOT) has regularly issued BOT bills and bonds as part of a set of OMO instruments. Under the inflation targeting regime adopted in 2000, the BOT has used a set of OMO instruments to manage liquidity in order to align the market rate with its policy rate, set by the MPC. Issuance of BOT bills and bonds, bilateral repurchase operations (BRP), FX swaps and outright purchase/sale of debt securities are the four main types of OMOs used.

Accumulation in international reserves over the past few decades, together with the legacy of financial market support in the late 1990s, has required a longer term liquidity management tool. While a variety of instruments is available to the BOT, the increasing stock of excess liquidity resulting from FX reserves accumulation called for a longer term liquidity absorption instrument. In light of this, BOT bills/bonds issuance has gained increasing importance due to its flexibility and range of maturities.

The BOT issues bills and bonds of different types at a wide range of maturities. Discount bills are issued at under 15-day, 3-month, 6-month and 1-year maturities. Fixed-coupon bonds are issued at 2 -year and 3-year maturities. At the same time, a floating-rate bond, linked to 3-month BIBOR, is currently issued at a 3-year maturity. Short-term bills of up to 6-month maturity are auctioned weekly while 1-year bills are issued on a monthly basis. Two year and 3-year fixed coupon bonds are issued in 
alternate months and the floating rate bond is issued every even month. BOT bills and bonds are issued via competitive, multiple-price auctions and with a non-competitive allotment.

To promote secondary market trading and enhance liquidity, bonds are reopened and bought back. The BOT reopens longer term BOT bills/bonds (of one-year maturity or longer) to achieve a targeted size to encourage secondary market trading and avoid fragmentation. Furthermore, the BOT also buys back longer term BOT bonds to help increase liquidity.

Close coordination between the BOT and Public Debt Management Office (PDMO) is essential to facilitate bond market development. The BOT assesses market conditions when determining the size of issuance and maturity distribution, and takes into account the government bond supply. The government, though PDMO, mainly issues bonds at longer maturities, from 3 years to 50 years. 
Annex III. Bank of Thailand's Planned Issuance for 2014

(Announced in December 2013)

\begin{tabular}{|l|r|r|r|}
\hline \multicolumn{1}{|c|}{ Type of Bond } & \multicolumn{1}{|c|}{$\begin{array}{c}\text { Issue Size per } \\
\text { Auction } \\
\text { (Million Baht) }\end{array}$} & $\begin{array}{r}\text { Outstanding per } \\
\text { Issue } \\
\text { (Million Baht) }\end{array}$ & $\begin{array}{c}\text { Number of } \\
\text { Issue } \\
\text { Per Year }\end{array}$ \\
\hline Discount Bond & $30,000-70,000$ & $30,000-70,000$ & $50-52$ \\
\hline - Cash Management Bill & $25,000-40,000$ & $25,000-40,000$ & $50-52$ \\
\hline - 3- and 6-month & $25,000-45,000$ & $75,000-135,000$ & 4 \\
\hline - 1-year & $20,000-40,000$ & $60,000-120,000$ & \\
\hline Fix-coupon Bond & \multicolumn{3}{|c|}{} \\
\hline - 2- and 3-year & $8,000-15,000$ & $\begin{array}{r}96,000-138,000 \\
\text { (re-open BOT162A) }\end{array}$ \\
\hline Floating-rate Bond & \multicolumn{3}{|c|}{ - 3-year }
\end{tabular}

Source: BOT (www.bot.or.th). 